\title{
Training on the Management of Zakat, Infaq and Shadaqah (ZIS) Productive in Kerinjing Village, Tanjung Raja District, Ogan Ilir Regency
}

\author{
Ichsan Hamidi ${ }^{1 *}$, Sukanto ${ }^{1}$, Dirta Pratama Atiyatna ${ }^{1}$ and Dwi Darma Puspita Sari ${ }^{1}$ \\ ${ }^{1}$ Faculty of Economics, Universitas Sriwijaya, South Sumatra, Indonesia \\ * Correspondence author: hamidi@fe.unsri.ac.id
}

Article Info: Received: 09 June 2021; Accepted: 03 November 2021; Published: 13 November 2021

\begin{abstract}
Zakat, Infaq and Shadaqah (ZIS) are very important pillars in Islam to improve the welfare of the community, especially in rural areas. The correct management of ZIS funds needs to be understood to the village, so that it is not only depleted in consumptive activities, but can be applied in productive activities to improve the economy. The existence of mosques in the village as ZIS fund managers is very important in its distribution appropriately and usefully, so it is necessary to provide training related to the productive management of ZIS to the administrators and youth of mosques in Kerinjing Village. The goal is so that the people in Kerinjing Village can optimize the potential of ZIS collected. This training method uses discussion and counseling to the participants, so as to create a productive training atmosphere and create improved welfare for the community. Through the implementation of zakat management training, Infaq and Shadaqah (ZIS) productive in Kerinjing Village, Tanjung Raja Subdistrict Ogan Ilir District has been able to understand ZIS management productively good and true islamicly.
\end{abstract}

Keywords: Zakat; Infaq; Shadaqah; Village

\section{How to Cite:}

Hamidi, I., Sukanto, Atiyatna, D.P. \& Sari, D.D.P. (2021). Training on the Management of Zakat, Infaq and Shadaqah (ZIS) Productive in Kerinjing Village, Tanjung Raja District, Ogan Ilir Regency. Sricommerce: Journal of Sriwijaya Community Services, 2(2): 169-176. DOI: https://doi.org/10.29259/jscs.v2i2.67

\section{INTRODUCTION}

Zakat, infaq and shadaqah are worships that contain two dimensions namely hablun min alAllah or vertical dimension and hablun min an-nas or horizontal dimension. Zakah when performed properly and sincerely will improve the quality of faith, cleanse and purify the soul and give away the property owned. On the other hand, zakat is one form of worship that celebrates social values and carries ritual and spiritual messages. If managed properly and trust, zakat will be able to improve the welfare of the people, able to improve the work ethic of the people and as an institution of economic equality (Efendi, 2017). Hafidhuddin (2006) said through eight asnaf financed by zakat as determined by the Quran zakat can serve social as a means of social security and a means of unifying the community in meeting the basic needs of each individual, eradicating poverty and the eradication of fellow Muslims, then as a softening of the heart and tools of the spread of Islam. Is not the alms used for the converts whose hearts are persuaded, which means the converts whose hearts are persuaded are those who should be given zakat as softening their hearts or the hearts of their people, or to strengthen islam in their hearts.

Zakat, Infaq and Shadaqah have great potential in improving the welfare of the people. However, there are still many Muslims who are able from the material side but still reluctant to pray. The potential of Zakat Indonesia on paper is quite a lot, reaching 6.5 trillion / year, but 
people's poverty is still quite high. In other words, welfare equality has not been achieved. Therefore, the role of Zakat Management Organizations such as Amil Zakat Agency (BAZ) and Amil Zakat Institutions (LAZ) are needed. In addition, the existing smoking wheels are very lame small and medium enterprises or non-formal sectors: STREET VENDORS and other non-formal businesses also need more capital, for that the entrepreneurs, street vendors who dhuafa (can not afford) should be given capital credit from the institution (Syaiful and Suwarno, 2015).

The meaning of zakat in terms of language comes from the word zaka (masdar form) which has the meaning: blessings, growth, clean, holy and good. Some of these meanings are very in accordance with the true meaning of zakat. It is said that blessings, because zakat will bring blessings to the property of someone who has done zakat. It is said to be sacred, because zakat can purify the owner of property from the nature of tama", shirk, miserly and greedy. It is said that tunbuh, because zakat will multiply the reward for the muzakki and help the difficulties of the mustahiq (Asnaini, 2008).

The purpose of formal zakat management is to: (1) improve the effectiveness and efficiency of services in the management of zakat, and (2) increase the benefits of zakat to realize the welfare of the community and poverty alleviation. The formulation of the above objectives if studied positively contains the understanding that given the huge potential of zakat, it is necessary to make institutional efforts in order for zakat services to run effectively (on target), and can be used to support programs to provide social protection guarantees and improve the welfare of the people (Fitri, 2017).

In this era of globalization the influence of foreign cultures is very important to be a concern. It can be seen, that with the presence of modern technology, whatever happens in the world can be known at that moment, either through television screens or tools what is often called the permeation of communication technology. Departing from this, religion plays a very important role in the life of mankind. Islam gives spirit and at the same time offers answers to things that cannot be solved. Indeed, on the one hand globalization has brought economic prosperity and the advancement of science and technology, but on the other hand it has also brought the impact of spiritual and personality crises. Similarly, with the role of zakat, infaq and shadaqah in improving the welfare of the people, there needs to be a ZIS global program that applies Islamic values and also improves the welfare of people, especially in rural areas. Therefore, to face these challenges, the teachings of religion in this case Islam is important because it will be a strong foundation in behaving. This is where ZIS will appear as a means of improving the economy of the villagers(Hamidi et al., 2020; Mukhlis et al., 2018).

In the Decree of the Minister of Religious Affairs No. 581 of 1999 concerning the implementation of Zakat mentioned that the types of activities of utilization of zakat funds are divided into two parts, namely First, the utilization of social-based zakat that is the distribution of zakat funds in the form of compensation for consumptive needs called compensation programs (karitas) or consumptive grants. Second, the utilization of zakat based on economic development is the distribution of zakat in the form of giving business capital to those who are entitled to receive (mustahiq) directly or indirectly, whose management can involve or not involve the target mustahiq. The distribution of zakat funds is directed at productive economic efforts, which are expected to raise the level of community welfare. It can be seen that there are still many weaknesses in the management of Zakat, Infaq and Shadaqah (ZIS) funds, especially in rural areas (Hamidi et al., 2019).

The main problem in the management of zakat is that almost all mustahiq who receive ZIS funds are only used for consumptive reasons, so it cannot improve the welfare of the people for the long term. This is due to the lack of understanding of the community, especially in the village related to the productive management pattern of ZIS. The same thing happened in Kerinjing Village which was the target of this devotion. Therefore, further training is needed to the kerinjing village community to improve the understanding of the community regarding the productive management of ZIS funds, with the hope that it will have a significant impact on improving the economy of kerinjing villagers in the long term by maximizing the potential in this village. 


\section{LITERATURE REVIEW}

\subsection{Zakat}

Islam is the second largest religion in the world, with nearly one billion followers in the world (Tarar and Riyaz, 2012). In the Quran which is the main basis of Islamic law often mentions about zakat accompanied by prayer. It can be concluded, that zakat is as obligatory as prayer, so that all Muslims in the world must heed the command of Allah SWT to give zakat. Allah says in sura alBaqarah verse 267:
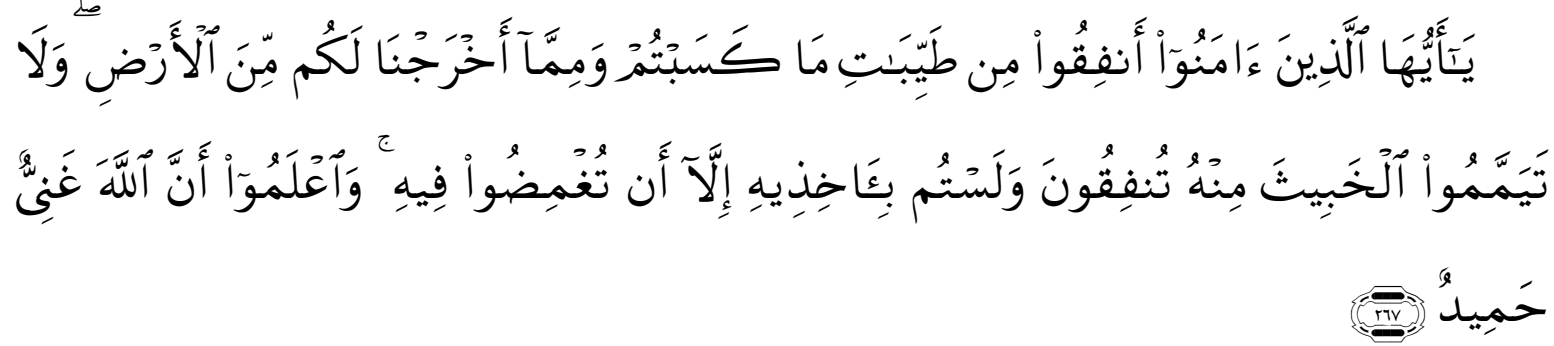

"267. Believers, spend out of what you have earned and of what We have produced for you from the earth. And do not choose the evil that you spend from it, but you do not take it but with your eyes against it. And know that Allah is All-Rich, All-Laudable".

Verses of the Quran above conclude that zakat is not only giving, but how to give the best to the needy, not giving bad. Yusoff (2008) said that zakat not only gives something to others on the basis of good deeds, but rather the assumption that zakat is an important pillar in Islam and is also a form of worship of Muslims to Allah SWT.

One of the reasons for the creation of zakat so that people will help each other. Because man is a social being, which means that man cannot live alone without the help of others. Zakat also teaches Muslims to respect each other, so that a peaceful and harmonious life is created (Abdullah and Suhaib, 2011).

The meaning of zakat in terms of language comes from the word zaka (masdar form) which has the meaning: blessings, growth, clean, holy and good. Some of these meanings are very in accordance with the true meaning of zakat. It is said that blessings, because zakat will bring blessings to the property of someone who has done zakat. It is said to be sacred, because zakat can purify the owner of property from the nature of tama", shirk, miserly and greedy. It is said that tunbuh, because zakat will multiply the reward for the muzakki and help the difficulties of the mustahiq (Asnaini, 2008; Hamidi et al. 2020). It is called the word zakat, as revealed in the word of Allah SWT in surah An-nur verse 56:

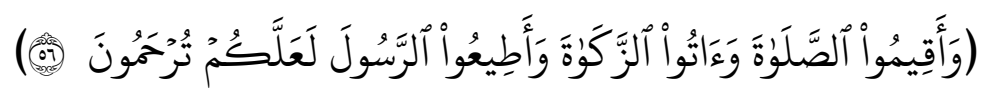

"Establish prayer, pay the poor-rate, and obey the Messenger, that you may be granted mercy"

Many experts define zakat. According to nawawi, the amount spent from the wealth is called zakat because it "adds much to make more meaningful and protects wealth and destruction". According to Ibn Taymiyah, the soul of the man who is blessed becomes clean and his wealth will be clean, clean and increase in meaning (Hamidi et al., 2019).

However, if there is none, then it is taken from the person who is obliged to provide for him while he is alive. But if it is not there, then it is taken from bayt al-mal and if this is also not possible then it is the responsibility of the whole Muslim. This is intended so that there is no delay in organizing the corpse due to the absence of assets to finance the process of organizing the corpse (Riyadi, 2013).

\subsection{Zakat Function}

In the Qur'an there are many verses that explain expressly command the implementation of zakat. The command of Allah to perform the zakat often coincides with the command to perform 
the prayer. This shows how important the role of zakat is in the lives of Muslims. The verse that contains the word zakat and accompanied by the word prayer.

According to Hamidi (2019) Zakat is the main worship of maliyah and prayer is the main of badaniyah worship. Therefore, we are not surprised that all scholars stipulate that : "denying the law of zakat (denying the obligatory) punished kufur, out of Islam. Muhammad (2011) also said Zakat can be used for social purposes, especially for those who belong to the asnaf / mustahiq that has been determined in the Quran because of the role and function contained in it so that zakat is seen as a religious levy that must be set aside by a Muslim or a body owned by Muslims in accordance with the provisions of religion. Zakat can prevent people from social inequality between the rich and the poor. Zakat can also foster and develop the stability of social life, economy, foster a sense of social responsibility. Helping, reducing and lifting the poor from economic and social difficulties, fostering and fostering the brotherhood of fellow human beings, and developing individual responsibilities to the interests of society and the public interest.

\subsection{Zakat Productive}

In the Decree of the Minister of Religious Affairs No. 581 of 1999 concerning the Implementation of Zakat mentioned that the types of activities of utilization of zakat funds are divided into two parts, namely First, the utilization of social-based zakat that is the distribution of zakat funds in the form of compensation for consumptive needs called compensation programs (karitas) or consumptive grants. Second, the utilization of zakat based on economic development is the distribution of zakat in the form of giving business capital to those who are entitled to receive (mustahiq) directly or indirectly, whose management can involve or not involve the target mustahiq. The distribution of zakat funds is directed at productive economic efforts, which are expected to raise the level of community welfare.

Al-Masyiqah (2007) said that productive Zakat or Zakat Investment according to the term is to seek the acquisition of property profits by doing business with zakat assets. Zakat investment can be divided into three parts. First, the investment of zakat assets by the mustahiq (people who have azakat) themselves. Second, the investment of zakat assets made by mustahiq. Third, the investment of zakat assets made by the ruler or the body of amil zakat. Hamidi (2019) also revealed that Zakat Productive as the inclusion of zakat funds separately or with other funds in the sector that generates profit (profitable). The benefits of zakat investment are intended for the benefit of zakat recipients in the short and long term while remaining guided by sharia principles.

\section{METHODS}

The implementation of community service in Kerinjing Village, Tanjung Raja subdistrict in Ogan Ilir, South Sumatra is Thursday, November 26, 2020. The method of implementation of devotion will be done using the method of lectures, tutorials and discussions. The systematic implementation of this devotional activity using lecture method where participants are given material on Zakat Management, Infaq and Shadaqah (ZIS) productive. Then it ends with a discussion with the participants.

\section{RESULT AND DISCUSSION}

\subsection{Implementation}

The training was conducted one full day, starting from 08.00 WIB to 15.00 WIB followed by 20 participants consisting of village devices, community leaders, religious leaders, and mosque youth. During the implementation of the training participants are very enthusiastic to follow each stage. The training was conducted one full day, starting from 08.00 WIB to 15.00 WIB followed by 20 participants consisting of village devices, community leaders, religious leaders, and mosque youth. During the implementation of the training participants are very enthusiastic to follow each stage. The training began with a speech from the Head of Kerinjing Village, followed by a speech by the 
team leader and a reading of the do"a. The event continued with the introduction and delivery of materials by the resource person with a duration of approximately 2 (two) hours. The training began with a speech from the Head of Kerinjing Village, followed by a speech by the team leader and a reading of the prayer. The event continued with the introduction and delivery of materials by the resource person with a duration of approximately 2 (two) hours.

The speaker himself is a competent person in his field, in addition to being a Lecturer at the Faculty of Economics, Sriwijaya University, the resource person is also active in various organizations and as a preacher (ustadz) who often fills lectures and fills friday khutbah"at and lectures at every major islamic events, so as to provide input and sharing experiences to participants. Many things and field experiences are conveyed by the resource person based on what has been done in several activities related to the implementation of Productive ZIS. This further adds insight and spirit of the trainees to further explore and develop the potential of the village community as a community that upholds Islamic values.

\subsection{Response of Participants}

The training was conducted one full day, starting from 08.00 WIB to 15.00 WIB followed by 20 participants consisting of village devices, community leaders, religious leaders, and mosque youth. The place used is the kerinjing village mosque which we think is quite representative to be used as a training ground, although not very spacious but quite comfortable. The training went smoothly and casually, but seriously in delivery. All participants were seated equipped with LCD, microphone and speaker speakers. so that the community can deeply explore and understand directly. In the implementation of village officials and the community is very helpful in the preparation of training infrastructure facilities.

The enthusiasm of the trainees was evident when the Q\&A session was opened about the problem of productive ZIS management. The resource person answers all the questions asked along with workable solutions to solve problems. The delivery of materials is done using simple language and easy to understand by the participants, so that the training and discussion run smoothly and apply to the desired objectives and objectives.

\subsection{Feedback from Participants}

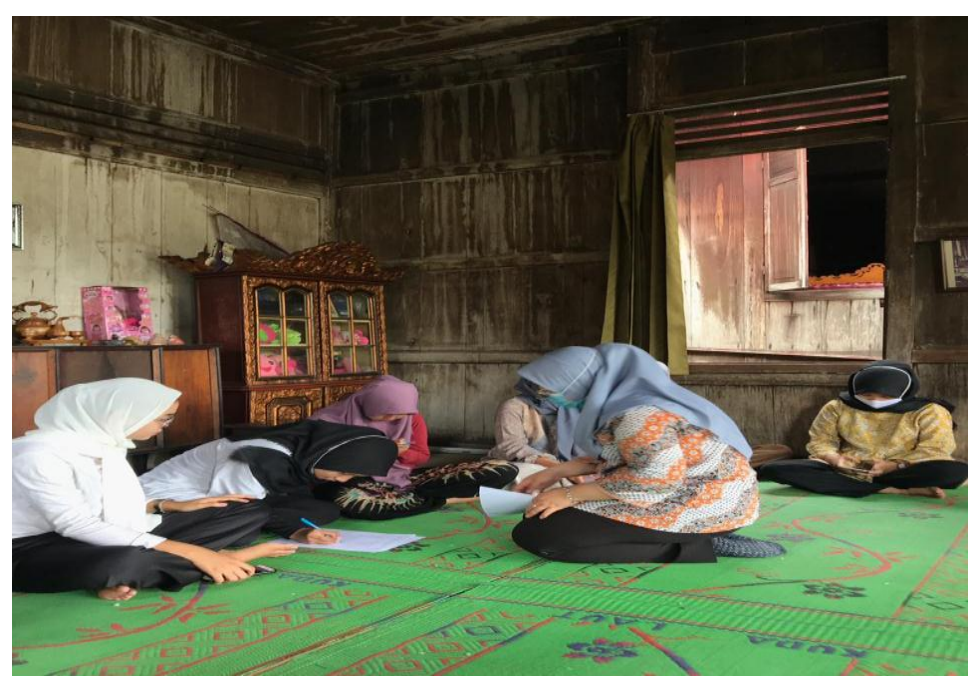

Figure 1. Feedback from Participant

This feedback is an important part of rural development planning training which aims to know the extent of participants' understanding and assessment of the materials provided. Feedback is intended to see how successful the devotion has been given by the presenter consisting of the delivery of materials, materials given, and the course of devotion organized by the committee. Ha I this is done to improve the course of devotion in the coming year. 
In this feedback session, each participant was asked to convey impressions and messages, as well as criticism and training suggestions directly. This is done to familiarize participants to dare to appear and open in conveying what is on their minds. Most of the participants gave a positive response, seen from some comments of participants who stated that the material that was presented gave more insight into the Management of Zakat, Infaq and Shadaqah (ZIS) productive so as to improve mindset, attitudes and behaviors, personality, ethics, manners and discipline, and social problems that exist in youth in the village.

\subsection{Discussion}

Training in the management of Zakat, Infaq and Shadaqah (ZIS) productive is very important to be applied in public life, especially in rural areas due to the lack of public understanding of the implementation of productive ZIS management, so that people have not dared to implement this program in their environment. Therefore, it is necessary for this training, especially for young people (mosque youth) in Kerinjing Village, so that in the future the management of this productive ZIS can help the economy of the community.

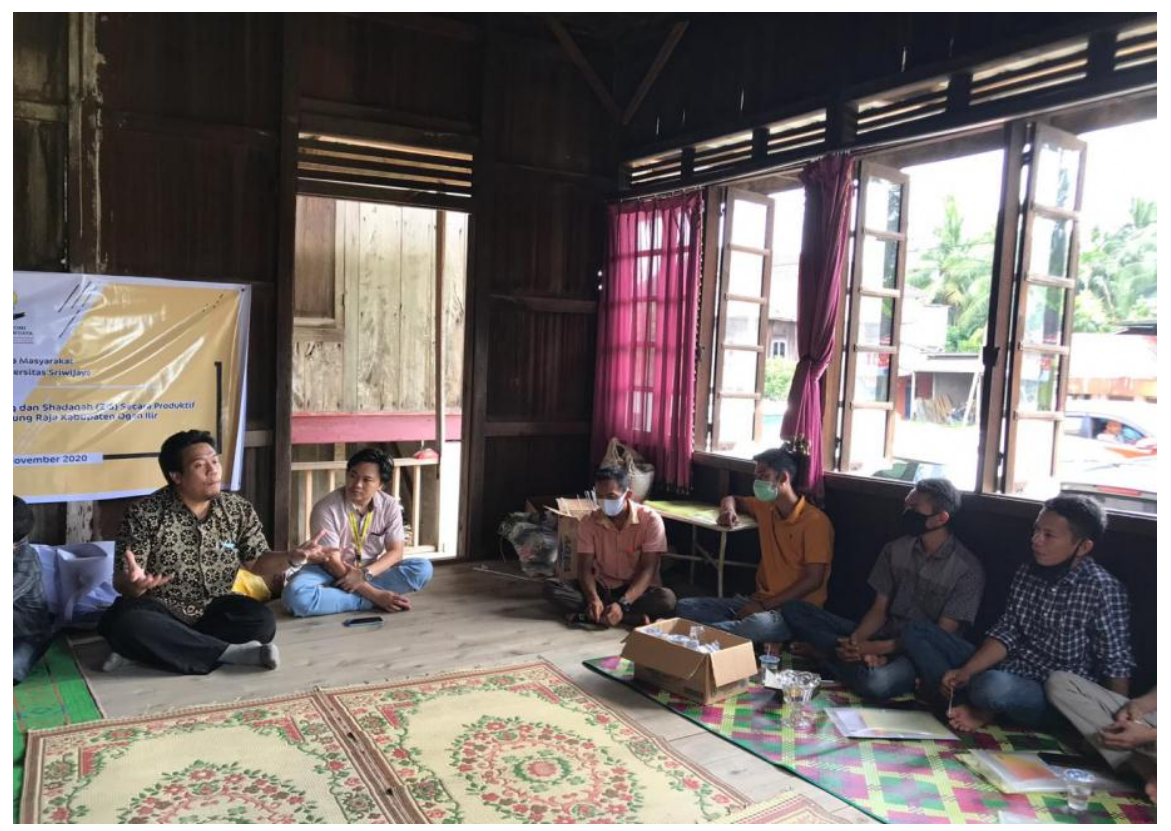

Figure 2. Presentation of ZIS Productive by Trainer

With this training, it is expected that the village community will no longer only manage ZIS consumptively, but ZIS can also be managed productively to be able to improve the economy of the community, especially MSMEs who need capital assistance for their business. It is expected that all parties who have participated in this training can lead and direct other communities about the management of ZIS productive well, so as to change the status of the community that was once mustahiq zakat into muzakki. If this can be achieved then it does not close the possibility of the community in Kerinjing Village, especially the young people can practice this knowledge to the villages aboutga, which can later become their practice in this world as a provision in the hereafter. Because Islam teaches that his people not only pursue life in this world but also prepare provisions for the life in the hereafter. 


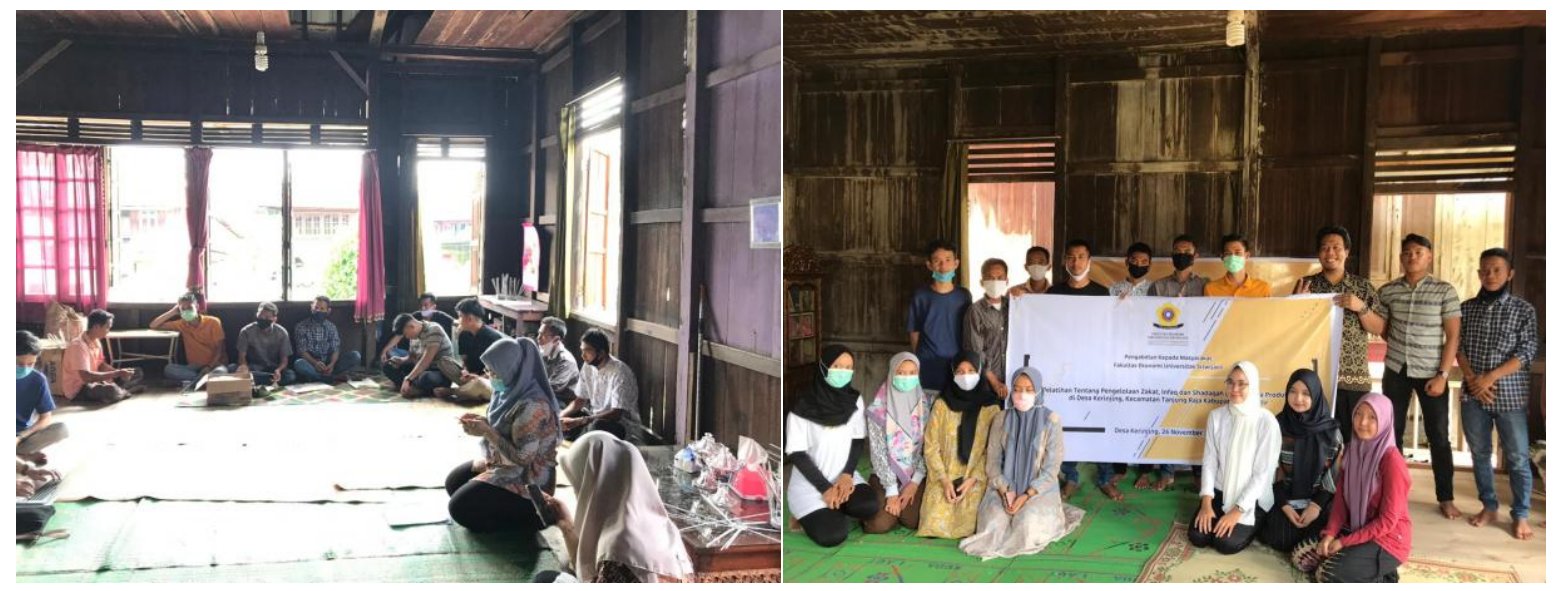

Figure 3. Discussion Between Trainer and Participant about ZIS Productive and Photo Session

This training begins by providing a deeper definition of Zakat, Infaq and Shadaqah (ZIS) Productive, so that people understand and understand deeply about ZIS in a productive manner that is good and correct. Then continued with the practice session by involving the participants as actors in managing productive ZIS practices, while the resource persons gave directions to them. This is done in no other way so that the participants can feel directly and learn to practice about the procedures of productive ZIS management that is good and islamic.

Kerinjing village basically has a very good Islamic culture, but the limitations of people's understanding of productive ZIS management cause the community has been only applying ZIS management consumptively, so there are still many who do not want to apply this practice. Whereas Islam teaches that the mustahiq zakat can be muzakki in the future. Therefore, this training is expected to be a forum for the community to learn and care for fellow communities, especially caring for Muslims who are still mustahiq zakat, it is expected that in the future many of the people of Kerinjing Village, Tanjung Raja Subdistrict, Ogan Ilir Regency, can become muzakki in the future, so that the ZIS funds raised can be more and can be managed productively sustainably.

\section{CONCLUSION}

Through the implementation of zakat management training, Infaq and Shadaqah (ZIS) productive in Kerinjing Village, Tanjung Raja Subdistrict Ogan Ilir District has been able to understand ZIS management productively good and true islamicly, so that in practice in this village kerinjing can involve all aspects of the community and become a charity jariah for all parties involved and participate from all aspects and help each other to manage ZIS productively in kerinjing village and improve muzakki in Kejing Village Tanjung Raja Subdistrict Regency of Ogan llir.

\section{SUGGESTION}

Further training activities are needed that are more technical, so that they can be understood and mastered more thoroughly related to productive ZIS management. It is expected to all village communities, community leaders, village devices, and young people in the village kerinjing Ogan llir district to be more actively looking for information and whenever possible follow socialization events about ZIS management productively. Training activities like this on an ongoing basis need to continue to be carried out on targets and targets more broadly, including villages / subdistricts / other districts / districts.

\section{ACKNOWLEDGEMENT}

This activities was funded by Faculty of Economics, Universitas Sriwijaya. Thank you to the Faculty of Economics, Universitas Sriwijaya, lecturers, committees, students and villagers who have 
participated in the successful implementation of this activity, so that it can run well and provide benefits to the people of Kerinjing Village.

\section{REFERENCES}

Abdullah, M., \& Suhaib, A.Q. (2011). The Impact of Zakat on Social life of Muslim Society. Pakistan Journal of Islamic Research, 8(1), 85-91.

Al-Masyiqah, Khalid Bin Ali. 2007. Fiqh Zakat Contemporary, Cet. 1, Translation by: Aan Wahyudin Yogyakarta. Ocean Science.

Asnaini. (2008). Zakat Produktif Dalam Perspektif Hukum Islam. Yogyakarta: Pustaka Pelajar.

Efendi, M. (2017). Pengelolaan Zakat Produktif Berwawasan Kewirausahaan Sosial dalam Pengentasan Kemiskinan di Indonesia. Al-Ahkam Jurnal Ilmu Syari'ah dan Hukum, 2(1). 2138.

Fitri, M. (2017). Pengelolaan Zakat Produktif sebagai Instrumen Peningkatan Kesejahteraan Umat. Economica: Jurnal Ekonomi Islam, 8(1), 149-173. doi:http://dx.doi.org/10.21580/economica.2017.8.1.1830.

Hafidhuddin, D. (2006). Zakat dalam perekonomian modern. Depok. Gema insani.

Hamidi, I., Atiyatna, D.P., \& Efriandy, I. (2020). The Effect of Zakat Productivity Toward Small Medium Enterprise Incomes of Recipient of Zakat. Proceedings of the 5th Sriwijaya Economics, Accounting, and Business Conference (SEABC 2019), 218-222, https://doi.org/10.2991/aebmr.k.200520.038. Retrieved from: https://www.atlantispress.com/proceedings/seabc-19/125940818.

Hamidi, I., Bashir, A., Atiyatna, D., Sukanto, S., \& Mukhlis, M. (2020). Pelatihan Manajemen Koperasi Syariah di Desa Kerinjing, Kabupaten Ogan Ilir, Sumatera Selatan. Sricommerce: Journal Of Sriwijaya Community Services, 1(1), 9-16. doi:https://doi.org/10.29259/jscs.v1i1.5.

Hamidi, I., Suhel, \& Novalia, N. (2019). The Mechanism of Zakat Productive Fund Management and Its Effect On The Income of Recipients of Zakat in Palembang City. In Proceedings of the 4th Sriwijaya Economics, Accounting, and Business Conference - SEABC, 659-668, DOI: 10.5220/0008443706590668.

Hamidi, I., Suhel, S., \& Latif, A. (2019). The effectivities of zakat productive funds toward zakat recipient income in Palembang. Jurnal Ekonomi Pembangunan, 17(1), 24-30. doi:https://doi.org/10.29259/jep.v17i1.8965.

Mukhlis, M.,Sukanto, S., \& Hamidi, I. (2018). Data dan Informasi Manfaat Dana Desa di Provinsi Sumatera Selatan. Jakarta: Badan Penelitian dan Pengembangan, Pendidikan dan Pelatihan, dan Informasi Kementrian Desa, Pembangunan Daerah Tertinggal dan Transmigrasi Republik Indonesia.

Riyadi, A. (2013). Upaya Pemberdayaan dan Peningkatan Keterampilan Pemulasaraan Jenazah di Wilayah Kecamatan Mijen Kota Semarang. Dimas: Jurnal Pemikiran Agama untuk Pemberdayaan, 13(2), 201-219. doi:http://dx.doi.org/10.21580/dms.2013.132.43.

Syaiful, S., \& Suwarno, S. (2016). Kajian Pendayagunaan Zakat Produktif Sebagai Alat Pemberdayaan Ekonomi Masyarakat (Mustahiq)Pada LAZISMU PDM Di Kabupaten Gresik. Benefit: Jurnal Manajemen dan Bisnis, 19(2), 150-160. doi:https://doi.org/10.23917/benefit.v19i2.2314.

Tarar, A., \& Madiha, R. (2012). Impact of Zakat on Economic : Structure and Implementation In Pakistan. Journal of Economics and Sustainable Development, 3(10), 151-155.

Wan Yusoff, W. (2008). Modern Approach of Zakat as an Economic and Social Instrument for Poverty Alleviation and Stability of Ummah. Jurnal Ekonomi \& Studi Pembangunan, 9(1), 105-118. 